\title{
Enhanced cadmium accumulation in maize roots-the impact of organic acids
}

\author{
Fang Han · Xiaoquan Shan · Shuzhen Zhang • \\ Bei Wen · Gary Owens
}

Received: 20 July 2006/ Accepted: 16 October 2006/ Published online: 7 November 2006

(C) Springer Science+Business Media B.V. 2006

\begin{abstract}
Low molecular weight organic acids are important components of root exudates and therefore, knowledge regarding the mechanisms of cadmium $(\mathrm{Cd})$ uptake and distribution within plants under the influence of organic acids, is necessary for a better understanding of $\mathrm{Cd}$ behavior in the plant-soil system. In this study, acetic and malic acids increased the uptake of Cd by maize (Zea mays L. cv. TY2) roots and enhanced $\mathrm{Cd}$ accumulation in shoots under hydroponic conditions. Concentration-dependent net $\mathrm{Cd}$ influx in the presence and absence of organic acids could be resolved into linear and saturable components. The saturable component followed Michaelis-Menten kinetics, which indicated that $\mathrm{Cd}$ uptake across the plasma membrane was transporter-mediated. While the $K_{m}$ values were similar, the $V_{\max }$ values in the presence of acetic and malic acids were respectively 6.0 and 3.0 times that of the control. Zinc
\end{abstract}

F. Han $\cdot$ X. Shan $(\bowtie) \cdot$ S. Zhang $\cdot$ B. Wen

State Key Laboratory of Environmental Chemistry and Ecotoxicology, Research Center for

Eco-Environmental Sciences, Chinese Academy

of Sciences, P.O. Box 2871, Beijing 100085, China

e-mail: xiaoquan@rcees.ac.cn

F. Han · G. Owens

Center for Environmental Risk Assessment and

Remediation, University of South Australia, Mawson

Lakes, SA 5095, Australia transporters were the most probable pathways for $\mathrm{Cd}$ accumulation. It was hypothesized that Cd(II)-organic acid complexes associated with the root zone, could decompose and liberate $\mathrm{Cd}^{2+}$ for subsequent absorption by maize roots; and that in the layer of the roots or within the root free space, depletion of $\mathrm{Cd}^{2+}$ was buffered by the presence of $\mathrm{Cd}(\mathrm{II})$-organic acid complexes. Plant response to elevated $\mathrm{Cd}$ levels involved overproduction of organic acids in maize roots as a resistance mechanism to alleviate $\mathrm{Cd}$ toxicity.

Keywords Cadmium - Maize (Zea mays) . Organic acids · Transporter $\cdot$ Uptake

\section{Introduction}

In recent years, concerns over the possible health and ecosystem effects of heavy metals in soils and accumulation in plants have increased. Low molecular weight organic acids are important components of root exudates. Under a wide range of soil conditions organic acids are typically negatively charged anions capable of reacting strongly with metal ions in both the soil solution and solid phases (Jones and Darrah, 1994). Organic acids are important soil components for the dissolution of metals from insoluble mineral phases in soil, increasing metal mobility 
in the vicinity of roots and enhancing metal phytoavailability to plants (LÕpez-Bucio et al., 2000).

Many studies have concentrated on the important role that organic acids play at the plant-soil interface. Organic acids can increase desorption of heavy metals and rare earth elements from soil and consequently increase metal concentrations in the soil solution (Qin et al., 2004; Shan et al., 2002). In pot experiments, organic acids triggered uranium accumulation in Indian mustard and Chinese cabbage (Huang et al., 1998), increased chromium accumulation in tomato (Srivastava et al., 1999), and enhanced accumulation of light rare earth elements in natural perennial fern fronds (Shan et al., 2003). In addition, under hydroponic conditions, lanthanum uptake by barley, maize and wheat roots was enhanced in the presence of organic acids (Han et al., 2005; Wang et al., 2004a, b).

Among the various heavy metals, cadmium (Cd) is of particular health concern, because $\mathrm{Cd}$ is a toxic element easily taken up via plant roots. Therefore, the public health risk through food chain exposure to $\mathrm{Cd}$ containing foodstuffs will increase significantly (Dudka and Miller, 1999). Cadmium is a trace contaminant in many commercial phosphate fertilizers and continued application of phosphate fertilizers to crops has led to contamination of large areas of agricultural land in many countries throughout the world due to the constant anthropogenic release of $\mathrm{Cd}$ from these fertilizers to the soil. The bioavailability of $\mathrm{Cd}$ in the soil-plant system is considered to be a key factor controlling plant uptake, and several papers have proposed the involvement of organic acid chelation in the process. Krishnamurti et al. (1997) demonstrated that various organic acids were able to influence the rate of $\mathrm{Cd}$ release from different soils and increase the solubility of $\mathrm{Cd}$ from bulk soils. Cieśliński et al. (1998) found that the high $\mathrm{Cd}$ accumulating durum wheat cultivar Kyle had significantly higher amounts of organic acids in the rhizosphere soil than that of the low accumulating cultivar Arcola, regardless of soil type. Statistically significant increases were observed in $\mathrm{Cd}$ accumulation by wheat with increasing concentrations of organic acids in pot experi- ments (Nigam et al., 2000). Under hydroponic conditions, $\mathrm{Cd}$ uptake and translocation in tomato plants increased after citric acid preincubation (Senden et al., 1995).

The enhancement of metal solubility in soils by organic acids and the subsequent metal uptake by plants has been mainly attributed to the metal chelating properties of the organic acids. One unresolved question is, in the vicinity of the root surface, how do organic acids exert their effects on plant uptake of metals? Are free metal ions or organic ligand-complexes taken up by plants? At the present time, further research is required to establish whether free metal ions are accumulated or if intact organo-metal complexes are transferred into the plant. In addition, plants vary in their ability to accumulate $\mathrm{Cd}$ (Hill et al., 2002), and differences in plant-soil interactions may affect the amounts of $\mathrm{Cd}$ entering the edible plant parts. For these reasons, it is essential to obtain knowledge of $\mathrm{Cd}$ uptake mechanisms and distribution processes of $\mathrm{Cd}$ in plants.

The aim of the present study was to investigate the mechanisms of enhanced $\mathrm{Cd}$ uptake by maize roots as influenced by organic acids. The cation channels and transporters, through which $\mathrm{Cd}$ was potentially absorbed into maize cytosol, were investigated and an improved understanding of the biological processes involved in Cd acquisition and distribution inside maize seedlings in the presence of organic acids was obtained.

\section{Materials and methods}

\section{Plant cultivation}

Maize (Zea mays L. cv. TY2) seeds were obtained from the Chinese Academy of Agricultural Sciences (Beijing, China). Seeds were first surface sterilized in $3 \% \mathrm{H}_{2} \mathrm{O}_{2}$, soaked in $2.8 \mathrm{mM}$ $\mathrm{Ca}\left(\mathrm{NO}_{3}\right)_{2}$ for $4 \mathrm{~h}$, then germinated on moist filter paper for $4 \mathrm{~d}$ in the dark and subsequently transferred into hydroponic solution. Maize seedlings were cultured in a nutrient solution consisting of major nutrients (one-third-strength of $1 \mathrm{mM} \mathrm{Ca}\left(\mathrm{NO}_{3}\right)_{2}, 0.5 \mathrm{mM} \mathrm{Ca}\left(\mathrm{H}_{2} \mathrm{PO}_{4}\right)_{2}, 0.5 \mathrm{mM}$ $\mathrm{K}_{2} \mathrm{SO}_{4}, 1 \mathrm{mM} \mathrm{MgSO}_{4}$ and $1.5 \mathrm{mM} \mathrm{NH}_{4} \mathrm{NO}_{3}$ ) and 
micronutrients (full-strength of $75 \mu \mathrm{M}$ EDTA-Fe, $46 \mu \mathrm{M} \mathrm{H} \mathrm{H}_{3} \mathrm{BO}_{3}, 9 \mu \mathrm{M} \quad \mathrm{MnSO}_{4}, 0.8 \mu \mathrm{M} \mathrm{ZnSO}_{4}$, $0.3 \mu \mathrm{M} \mathrm{CuSO}{ }_{4}$ and $\left.0.8 \mu \mathrm{M} \mathrm{Na}_{2} \mathrm{MoO}_{4}\right) \cdot \mathrm{ZnSO}_{4}$ was equilibrated with $\mathrm{H}_{4}$ EDTA before addition to the nutrient solution (Norvell and Welch, 1993). The solution was buffered to $\mathrm{pH} 5.8$ with $2 \mathrm{mM}$ Mes-Tris. Plants were grown in a plant growth chamber with operating conditions maintained at $16 \mathrm{~h}$ light $/ 8 \mathrm{~h}$ darkness at $25 / 18^{\circ} \mathrm{C}$, respectively, relative humidity between $50 \%$ and $60 \%$ and a light intensity of $300 \mu \mathrm{mol}$ photons $\mathrm{m}^{-2} \mathrm{~s}^{-1}$. Aerated nutrient solutions were changed every $3 \mathrm{~d}$. In all studies, 12-days-old uniform maize seedlings were used.

Bacterial growth in nutrient solutions was minimized by soaking and cleaning all glassware prior to use with sodium hypochlorite; autoclaving macronutrient stock solution and deionized water, and adding $30 \mathrm{mg} \mathrm{l}^{-1}$ of the antibiotic cefotaxime to all assay solutions (Bell et al., 2003).

Effect of molar concentration ratio (organic acids: $\mathrm{Cd}$ ) on $\mathrm{Cd}$ uptake by maize roots

Uniform maize seedlings grown in nutrient solutions containing $5 \mu \mathrm{M} \mathrm{Cd}$ in the absence of organic acids were used as controls. Seven different molar concentration ratios $(1: 1,2: 1,3: 1,5: 1$, 10:1, 50:1 and 100:1) of acetic or malic acid to $\mathrm{Cd}$ were examined. Acetic and malic acids were chosen as representative organic acids because they are ubiquitous and abundant in many plant exudates (Cieśliński et al., 1998; Jones, 1998). Maize seedlings were harvested $2 \mathrm{~d}$ after exposure to amended solutions. During this period fresh incubation solution was replaced every $12 \mathrm{~h}$. Roots were desorbed with $5 \mathrm{mM}$ ice-cold $\mathrm{CaCl}_{2}$ (5 mM Mes-Tris, pH 6.0) for 15 min then gently blotted, weighed and digested for final determination of Cd. Experiments were performed in quadruplicate. The use of $5 \mathrm{mM}$ ice-cold $\mathrm{CaCl}_{2}$ for desorption was previously reported by Rauser (1987), who suggested that $5 \mathrm{mM} \mathrm{CaCl}_{2}$ was effective in removing the $\mathrm{Cd}$ adsorbed on cell walls of maize roots. A similar desorption step was also used by Hart et al. (1998) and Lombi et al. (2002).
Time-dependent kinetics of Cd uptake by maize roots under the influence of organic acids

Uniform maize seedlings were transferred to a control nutrient solution containing $5 \mu \mathrm{M} \mathrm{Cd}$ without added organic acids, while in the other two uptake experiments $250 \mu \mathrm{M}$ of either acetic or malic acids were added separately to control solutions. At increasing time intervals following exposure of seedlings to the incubation solution $(5,10,20,40,60,90$ and $120 \mathrm{~min}$, and 4, 6, 12, 24, 36 and $48 \mathrm{~h}$ ) maize seedlings were harvested. During short-term uptake experiments (0$120 \mathrm{~min}$ ), subsamples of roots were collected and total $\mathrm{Cd}$ determined without desorption, while the remaining roots were desorbed in $5 \mathrm{mM}$ ice-cold $\mathrm{CaCl}_{2}$ (5 mM Mes-Tris, $\mathrm{pH}$ 6.0) for $15 \mathrm{~min}$ prior to $\mathrm{Cd}$ determination. During long-term uptake experiments $(0-2 \mathrm{~d})$, the incubation solutions were replaced every $12 \mathrm{~h}$, and all harvested maize roots were desorbed and digested for $\mathrm{Cd}$ determination. After $2 \mathrm{~d}$ exposure, maize shoots were also harvested and separated into stems and leaves. Roots, stems and leaves of maize seedlings were dried at $60^{\circ} \mathrm{C}$ for $2 \mathrm{~d}$ and finely ground. An aliquot of dried plant material $(0.200 \mathrm{~g})$ was digested for $\mathrm{Cd}$ determination. All experiments were performed in quadruplicate.

Concentration-dependent kinetics of $\mathrm{Cd}$ uptake by maize roots under the influence of organic acids

Three serial experiments were performed simultaneously to test root uptake of $\mathrm{Cd}$ at different $\mathrm{Cd}$ concentrations. Uniform maize seedlings were incubated with fresh nutrient solutions containing various concentrations of $\mathrm{Cd}(0,0.25,0.50,1.0$, $1.5,2.0,2.5,3.0,3.5,4.0,5.0 \mu \mathrm{M} \mathrm{Cd})$. In two of these experiments, acetic and malic acids were added, separately, at a molar concentration ratio of 50:1 (organic acid:Cd). After incubation for $20 \mathrm{~min}$, seedlings were harvested, and the roots desorbed in $5 \mathrm{mM}$ ice-cold $\mathrm{CaCl}_{2}$ (5 mM MesTris, $\mathrm{pH}$ 6.0) for $15 \mathrm{~min}$. The concentration of $\mathrm{Cd}$ in the maize roots was quantified following acid digestion. Each serial experiment was performed in quadruplicate. 
Effects of various blockers of cation channels on $\mathrm{Cd}$ influx into maize roots

Uniform maize seedlings were incubated in nutrient solutions amended with either $0.50 \mathrm{mM}$ verampamil (ACROS, Fisher Company, Pittsburgh, PA, USA), diethyl pyrocarbonate (DEPC, AVOCADO, Johnson Matthey Company, Ward Hill, MA, USA) or tetraethylammonium chloride (TEA-Cl, Alfa Aesar, Johnson Matthey Company, Ward Hill, MA, USA). Unamended nutrient solution was used as a control. These three compounds have previously been identified as cation channel blockers by Essah et al. (2003) and Montague (1993), who also reported their appropriate application concentrations. Cd concentration was maintained at $5.0 \mu \mathrm{M}$ during this experiment. Acetic and malic acids were applied at a molar concentration ratio of 50:1 (organic acid:Cd). Maize seedlings were harvested after 4 $\mathrm{h}$ incubation. Roots were desorbed and acid digested prior to final determination of $\mathrm{Cd}$. All experiments were performed in quadruplicate.

Effect of $\mathrm{Zn}$ or Fe deficiency on Cd uptake by maize roots

$\mathrm{Zn}$ or Fe deficiency was induced in uniform maize seedlings by replacing a full nutrient solution with a nutrient solution without $\mathrm{Zn}$ or $\mathrm{Fe}$ for $6 \mathrm{~d}$ (Lombi et al., 2002). The seedlings were subsequently incubated in a $5.0 \mu \mathrm{M}$ Cd uptake solution with and without organic acids. The molar concentration ratio was maintained at 50:1 (organic acid:Cd). After $20 \mathrm{~min}$ exposure, maize roots were harvested, desorbed, and digested prior to $\mathrm{Cd}$ determination. All experiments were performed in quadruplicate.

\section{Effect of Zn concentration on Cd accumulation by maize roots}

Uniform maize seedlings grown in nutrient solutions were transferred to treatment solutions containing $5.0 \mu \mathrm{M}$ Cd without organic acids and increasing concentrations of $\mathrm{Zn}$, supplied as $\mathrm{Zn}\left(\mathrm{NO}_{3}\right)_{2}(0,2.5,5.0,10,25,50,100,175$ and $250 \mu \mathrm{M} \mathrm{Zn}$ ). Maize seedlings were also incubated in the presence of $250 \mu \mathrm{M}$ organic acid. In these treatment solutions the $\mathrm{Zn}$ concentration was maintained at $100 \mu \mathrm{M}$ while the $\mathrm{Cd}$ concentration remained at $5.0 \mu \mathrm{M}$. Seedlings were harvested 20 min after incubation commenced and maize roots were desorbed and digested with acid prior to Cd determination. All experiments were performed in quadruplicate. The dose of $\mathrm{Zn}$ used in the present study is very low compared with the doses used in other studies or present in contaminated soils (Keller et al., 2003; Robinson et al., 1998; Schwartz et al., 2003; Zhao et al., 2003).

Root organic acid extraction and determination

Maize seedlings were incubated for $2 \mathrm{~h}$ in a number of treatment solutions, including a control nutrient solution or nutrient solution containing 5.0 $\mu \mathrm{M}$ Cd with and without organic acids. At the end of the experiments, roots were cut off, gently blotted, weighed and frozen with liquid $\mathrm{N}_{2}$ (Pellet et al., 1995). The frozen roots were ground under the protection of liquid $\mathrm{N}_{2}$ and mixed with 95\% ethanol in a chilled mortar. The resulting mixture was centrifuged at $30,000 \mathrm{~g}$ for $30 \mathrm{~min}$ at $4^{\circ} \mathrm{C}$ (Centrifuge 5804R; Eppendorf, Hamburg, Germany). The supernatant was retained, and the pellet was resuspended in $95 \%$ ethanol and respun. This procedure was repeated four times for each sample and the combined supernatants, retained from the four extractions, evaporated to dryness under vacuum. The residue was redissolved in $15 \mathrm{ml}$ of Milli-Q water (Easy-pure, Dubuque, IA, USA), and filtered through a disposable syringe filter $(0.2 \mu \mathrm{m})$.

Organic acids in root homogenates were analyzed with a capillary electrophoresis (CE) system (P/ACE MDQ; Beckman Instruments, Fullerton, CA, USA) controlled by a Pentium II computer interfaced via PACE 1.2.1 software (Beckman Instruments) according to Piñeros et al. (2002) with little modification. Organic acids were separated in a $60-\mathrm{cm}$ capillary $(75 \mu \mathrm{m}$ i.d.) with a constant separation voltage of $-20 \mathrm{kV}$ at $25^{\circ} \mathrm{C}$. Peaks were detected with a UV absorbance detector at a wavelength of $214 \mathrm{~nm}$, and were first identified on the basis of their migration time, with subsequent confirmation by spiking samples with organic acids standards. 
Membrane permeability

Maize seedlings were incubated in different treatment solutions for $2 \mathrm{~d}$. During this period fresh incubation solution was replaced every $12 \mathrm{~h}$. Treatment solutions including control nutrient solutions or nutrient solutions amended with $5.0 \mu \mathrm{M}$ Cd with and without organic acids. At the end of the experiments, roots were thoroughly washed twice with $5 \mathrm{mM}$ ice-cold $\mathrm{CaCl}_{2}(5 \mathrm{mM}$ Mes-Tris, $\mathrm{pH}$ 6.0) to eliminate nutrient solution from the apoplast and then blotted on filter paper. Each sample consisted of one seedling which was then introduced to $25 \mathrm{ml}$ of fresh $0.2 \mathrm{mM} \mathrm{CaSO}_{4}$ solution. Seedlings were incubated for $4 \mathrm{~h}$ in a water bath at $25^{\circ} \mathrm{C}$ with gentle shaking (LIamas et al., 2000). Potassium $\left(\mathrm{K}^{+}\right)$ efflux to the external solution, as well as $\mathrm{K}^{+}$ remaining in the roots, was measured using an inductively coupled plasma-optical emission spectrometer (ICP-OES) (Optima 2000DV, Perkin Elmer Co., USA; detection limit: $40 \mathrm{mg} \mathrm{l}^{-1}$ ). In order to determine $\mathrm{K}^{+}$in roots, following incubation, roots were washed, homogenized in $10 \mathrm{ml}$ Milli-Q water, boiled for $30 \mathrm{~min}$ and centrifuged at $5,000 \mathrm{~g}$, and $20^{\circ} \mathrm{C}$ for $10 \mathrm{~min}$. The supernatant was then analyzed using ICP-OES to determine the $\mathrm{K}^{+}$content. All experiments were performed in quadruplicate.

\section{Determination of $\mathrm{Cd}$}

High Cd concentrations were determined by inductively coupled plasma-optical emission spectrometry (ICP-OES, detection limit of $4 \mu \mathrm{g} \mathrm{l}^{-1}$ ) (Optima 2000DV, Perkin-Elmer Co., Boston, MA, USA), while low Cd concentrations were determined by inductively coupled plasma-mass spectrometry (ICP-MS, detection limit of $3.6 \mathrm{ng} \mathrm{l}^{-}$ 1) $(X$-series, Thermo Electron, Waltham, MA, USA). Cd in plant materials was determined following acid digestion. Fresh plant material $(0.25 \mathrm{~g})$ was digested with $3 \mathrm{ml}$ of $\mathrm{HNO}_{3}-\mathrm{HClO}_{4}$ $(2: 1, \mathrm{v} / \mathrm{v})$ under high-pressure conditions and transferred quantitatively into a $10 \mathrm{ml}$ volumetric flask and diluted to volume with $2 \% \mathrm{HNO}_{3}$. The accuracy of both ICP-OES and ICP-MS was checked using a certified reference material peach leave (national first-class environmental standard sample, GBW 08501, PR China), in which the Cd content is certified to be $0.018 \mu \mathrm{g} \mathrm{g}^{-1} \mathrm{~d}$. wt.

Data analysis

Data analysis was performed using the commercially available statistical software, MICROCAL_ORIGIN_6.1 (Microcal Software, Northampton, MA, USA) or SPSS 12.0 for windows (SPSS, Chicago, IL, USA).

Speciation calculations

The chemical speciation of $\mathrm{Cd}$ in incubation solutions containing organic acids was predicted using the computer program MINEQL (Westall et al., 1976) and the stability constants of Smith et al. (1997). Full consideration was given to mole balances, relevant thermodynamic equilibrium constants and ionic strengths in performing these calculations.

\section{Results}

Influence of molar concentration ratio of organic acids to $\mathrm{Cd}$ on the uptake of $\mathrm{Cd}$ by maize roots

As can be seen from Fig. 1, both acetic and malic acids stimulated the uptake of $\mathrm{Cd}$ by maize roots, which is shown as a function of the molar concentration ratio of organic acid to $\mathrm{Cd}$. At the concentration range of organic acids considered here, acetic and malic acids exerted a similar trend, with acetic acid showing a greater enhancement effect than that of malic acid. The content of $\mathrm{Cd}$ in the roots increased steadily from the ratio of $1: 1$ to $50: 1$. The maximum enhancement effect was observed at the ratio of 50:1. Under optimal conditions the $\mathrm{Cd}$ content of desorbed maize roots increased by 110 and $75 \%$ in the presence of acetic and malic acids, respectively, after $2 \mathrm{~d}$ of exposure, compared with the control $(P<0.01)$. The contents of $\mathrm{Cd}$ remaining in the roots at the ratio of $50: 1$ were 31 and $24 \%$ higher than those at the ratio of $2: 1$ due to the application of acetic and malic acid, respectively $(P<0.05)$. The $\mathrm{Cd}$ content of the roots decreased with a further 


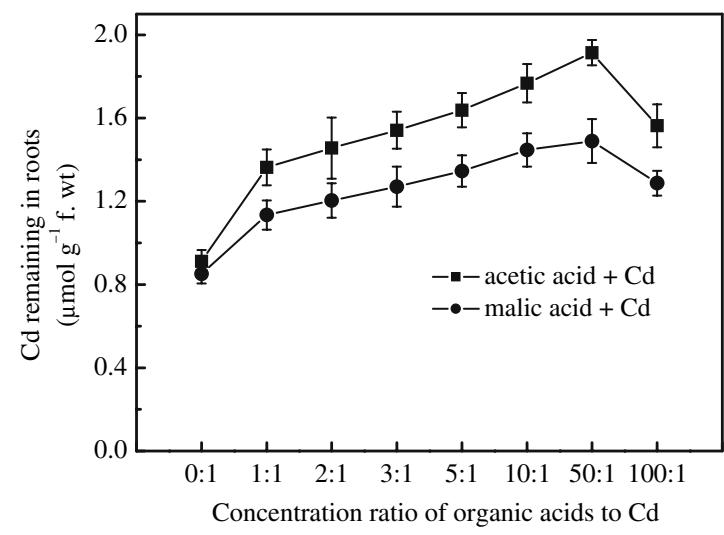

Fig. 1 Effect of molar concentration ratio (organic acid:Cd) on the uptake of Cd by maize (Zea mays L.) roots. Values are means $( \pm \mathrm{SE})$ of four replicates. The molar concentration ratio $(0: 1)$ indicates maize roots treated with $\mathrm{Cd}$ but without the application of organic acids. Cd concentration was maintained at $5.0 \mu \mathrm{M}$. Uptake for $2 \mathrm{~d}$, desorption in $5 \mathrm{mM}$ ice-cold $\mathrm{CaCl}_{2}$ ( $5 \mathrm{mM}$ MesTris, $\mathrm{pH}$ 6.0) for $15 \mathrm{~min}$

increase in the organic acid to Cd ratio to $100: 1$. We used 50:1 (organic acid:Cd) as molar concentration ratio in all our subsequent studies.

Time dependent $\mathrm{Cd}$ uptake by maize roots under the influence of organic acids

The Cd uptake patterns were similar between control and organic acid treated solutions for both short and long-term experiments. However, in comparison to the control, $\mathrm{Cd}$ accumulation in maize roots was consistently greater in the presence of organic acids. For maize roots without $\mathrm{CaCl}_{2}$ desorption (Fig. 2a), the Cd uptake was biphasic, exhibiting an initial $20 \mathrm{~min}$ rapid phase and a later slower linear phase 20-120 min. For maize roots with $\mathrm{CaCl}_{2}$ desorption the dynamic processes of the three uptake experiments were also biphasic, but the slower linear phase of accumulation between $10 \mathrm{~min}$ and $120 \mathrm{~min}$ dominated the uptake curve. After $2 \mathrm{~h}$ exposure, total $\mathrm{Cd}$ in the desorbed maize roots was 3.0 and 2.2 times greater than that of the control $(P<0.05)$ under the influence of acetic and malic acid, respectively.

Long term exposure to $\mathrm{Cd}$ also showed biphasic uptake, a rapid uptake phase in the first $6 \mathrm{~h}$, followed by a slow unsaturated phase up to
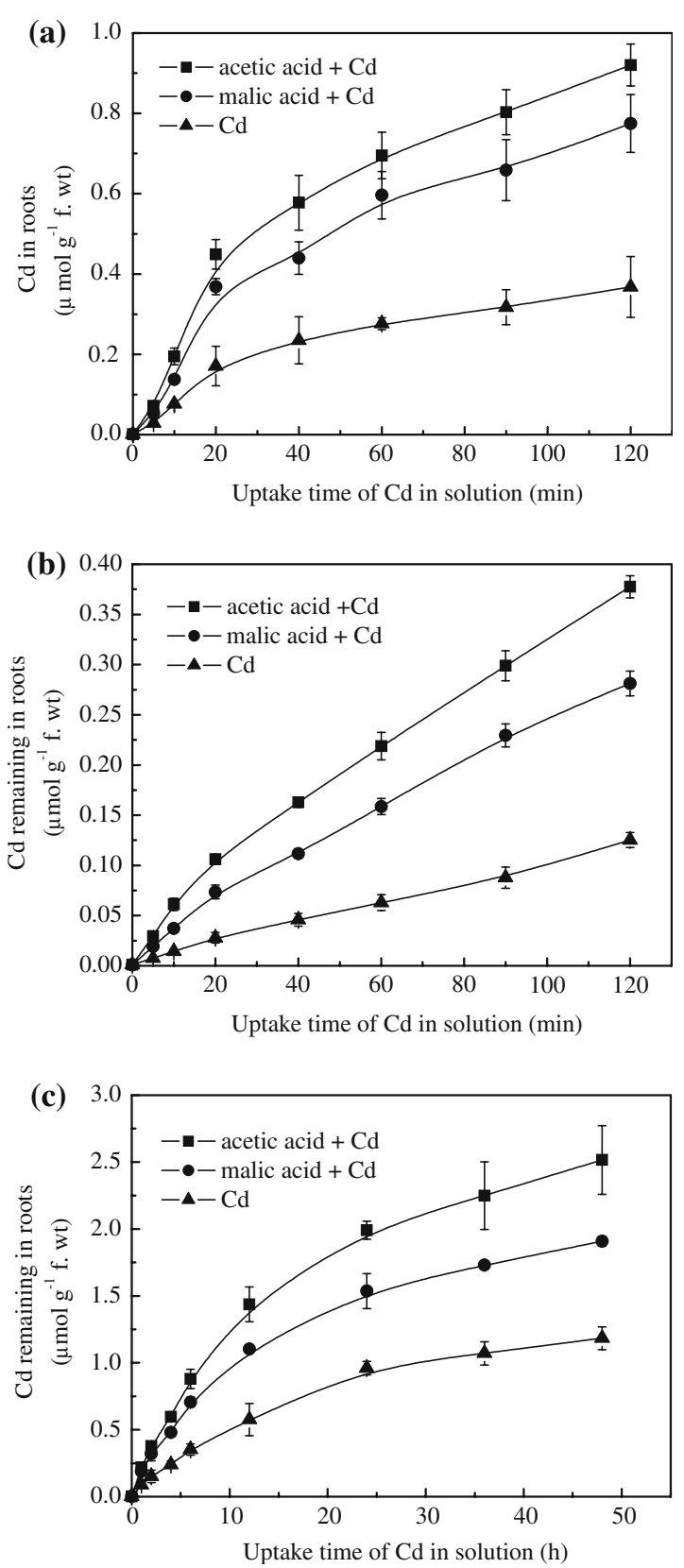

Fig. 2 Time-dependent Cd uptake by maize (Zea mays L.) roots for short term exposure $(2 \mathrm{~h})$ without (a) or with (b) desorption in $5 \mathrm{mM}$ ice-cold $\mathrm{CaCl}_{2}$ (5 mM Mes-Tris, $\mathrm{pH}$ 6.0) for $15 \mathrm{~min}$, and for long term exposure (2 d) with desorption (c). Values represent means $( \pm S E)$ of four replicates. Cd concentration was maintained at $5.0 \mu \mathrm{M}$. The molar concentration ratio (organic acid:Cd) was 50:1

$48 \mathrm{~h}$ (Fig. 2c). The uptake did not reach saturation, because maize seedlings were still growing and no equilibrium was reached. Compared with 


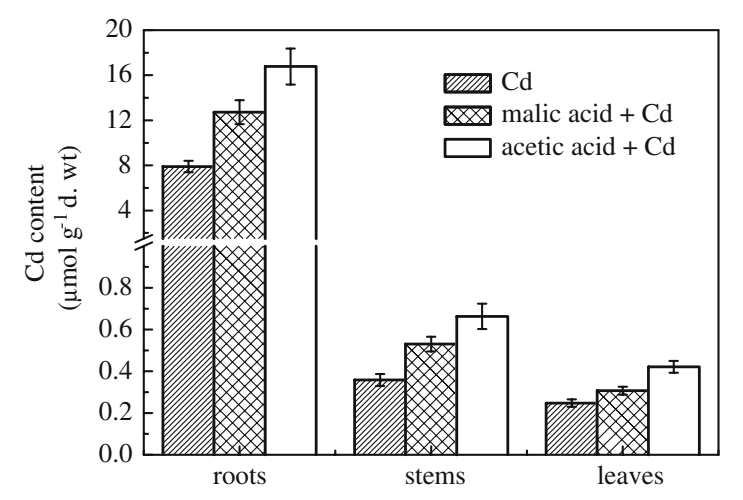

Fig. 3 Contents of $\mathrm{Cd}$ in dry matter of maize (Zea mays L.) roots, stems and leaves under the influence of organic acids. Values are means $( \pm \mathrm{SE})$ of four replicates. Uniform maize seedlings were harvested after $2 \mathrm{~d}$ incubation with $\mathrm{Cd}$ concentration maintained at $5.0 \mu \mathrm{M}$. The molar concentration ratio (organic acids: $\mathrm{Cd}$ ) was 50:1

Cd uptake in the absence of organic acids, $\mathrm{Cd}$ content in the desorbed maize roots increased by 113 and $61 \%$ for acetic and malic acid respectively when exposed for $48 \mathrm{~h}$, (Fig. $3, P<0.01$ ). Treatment with organic acids not only increased the $\mathrm{Cd}$ absorption by maize roots, but also increased $\mathrm{Cd}$ concentrations in maize shoots. Acetic acid was more effective than malic acid in enhancing $\mathrm{Cd}$ uptake. After $48 \mathrm{~h}$ of exposure, acetic and malic acids had increased the content of $\mathrm{Cd}$ in maize stems by 85 and $48 \%$, respectively (Fig. 3, $P<0.01$ ), and Cd content in the leaves by 70 and $24 \%$ over that of the control (Fig. 3, $P<0.05)$.

\section{Concentration-dependent kinetics of $\mathrm{Cd}$} uptake by maize roots under the influence of organic acids

The linear nature of short-term, time-dependent accumulation of $\mathrm{Cd}$ (Fig. 2b) suggests that unidirectional $\mathrm{Cd}$ influx into the root symplast occurs regardless of the application of organic acids. Thus, we chose a 20 min uptake period to investigate the concentration-dependent uptake kinetics of $\mathrm{Cd}$. This relatively short uptake period allowed us to investigate uptake while minimizing the possibility of $\mathrm{Cd}$ efflux across the plasma membrane back into the external solution. The concentration-dependent uptake kinet-
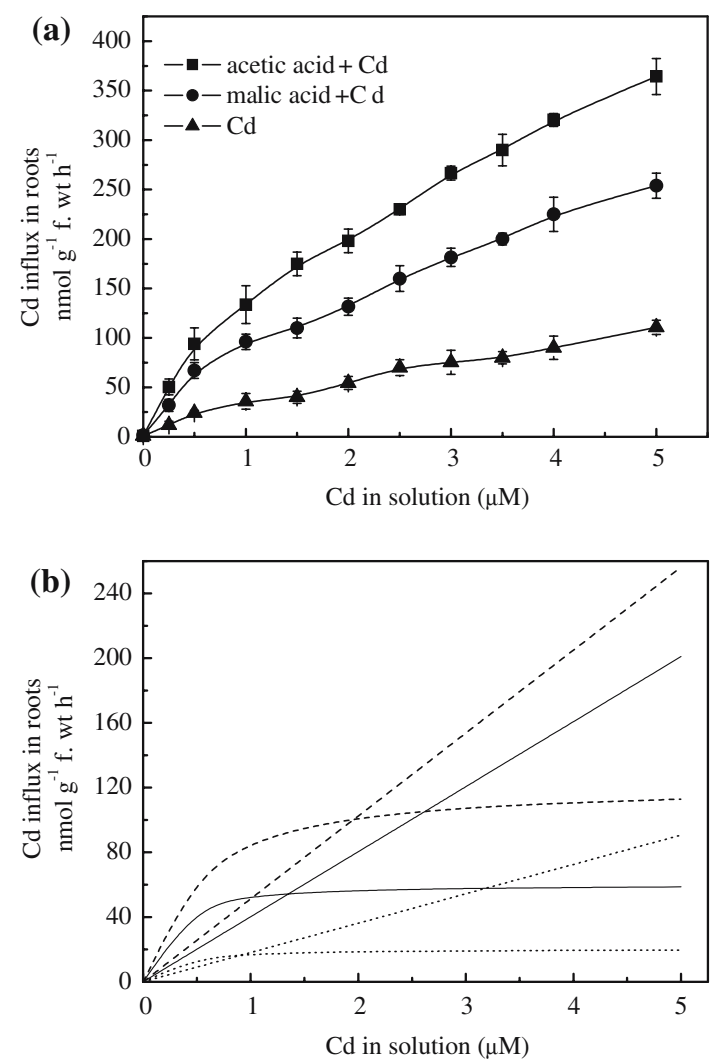

Fig. 4 Concentration-dependent uptake kinetics of $\mathrm{Cd}$ into maize (Zea mays L.) roots. Roots were immersed into a solution containing different $\mathrm{Cd}$ levels. The molar concentration ratio (organic acid:Cd) was 50:1. Exposure for $20 \mathrm{~min}$ with desorption in $5 \mathrm{mM}$ ice-cold $\mathrm{CaCl}_{2}(5 \mathrm{mM}$ Mes-Tris, pH 6.0) for 15 min: (a) Overall kinetics curves for Cd uptake influx. Data points and error bars represent means $( \pm$ SE) of four replicates; (b) Resolution of overall kinetics curves into saturable and linear components. $\mathrm{Cd}$ $(\cdots \cdots \cdots)$, malic acid $+\mathrm{Cd}(-)$, acetic acid $+\mathrm{Cd}(---)$

ics of Cd influx was characterized by smooth, nonsaturating curves (Fig. 4a). Organic acids increased $\mathrm{Cd}$ uptake over the whole range of uptake solution $\mathrm{Cd}$ concentrations. The uptake kinetics of $\mathrm{Cd}$ in the absence and presence of acetic and malic acids were similar (biphasic) and could be graphically resolved into saturable and linear components through a modified Michaelis-Menten kinetics model: $V=a C+$ $V_{\max } C /\left(K_{m}+C\right) \quad$ (Fig. 4b). This resolution showed that acetic and malic acid could increase $V_{\max }$ for $\mathrm{Cd}$ influx by 6.0 and 3.0 times, respectively, relative to the control $(P<0.001)$. 
Table 1 Kinetic parameters of Cd uptake in maize (Zea mays L.) roots in the presence of acetic and malic acids

\begin{tabular}{lll}
\hline Treatment & $\begin{array}{l}V_{\max }\left(\mathrm{nmol} \mathrm{g}^{-1} \text { root }\right. \\
\left.\text { f. } w \mathrm{~h} \mathrm{~h}^{-1}\right)\end{array}$ & $K_{m}(\mu \mathrm{M})$ \\
\hline Cd & $20.31 \pm 3.30$ & $0.20 \pm 0.03$ \\
Malic acid $+\mathrm{Cd}$ & $60.39 \pm 12.14$ & $0.16 \pm 0.02$ \\
Acetic acid $+\mathrm{Cd}$ & $122.6 \pm 20.12$ & $0.43 \pm 0.03$ \\
\hline
\end{tabular}

Data are means $\pm \operatorname{SE}(n=4)$

However, both organic acids had no significant effect on $K_{m}$ (Table 1).

Contribution of $\mathrm{Ca}^{2+}, \mathrm{Na}^{+}$and $\mathrm{K}^{+}$cation channels to $\mathrm{Cd}$ influx

We selected three cation channel blockers: verampamil (a $\mathrm{Ca}^{2+}$ channel blocker), diethyl pyrocarbonate (DEPC, a $\mathrm{Na}^{+}$channel blocker), and tetraethylammonium chloride (TEA-Cl, a $\mathrm{K}^{+}$ channel blocker) to study the contribution of various cation channels to $\mathrm{Cd}$ influx into maize roots under the influence of organic acids. All of these blockers had no statistically significant inhibition effect on $\mathrm{Cd}$ influx into all treated maize roots (Fig. 5). Therefore, our study does not support any $\mathrm{Cd}$ uptake through $\mathrm{Ca}^{2+}, \mathrm{Na}^{+}$and $\mathrm{K}^{+}$cation channels.

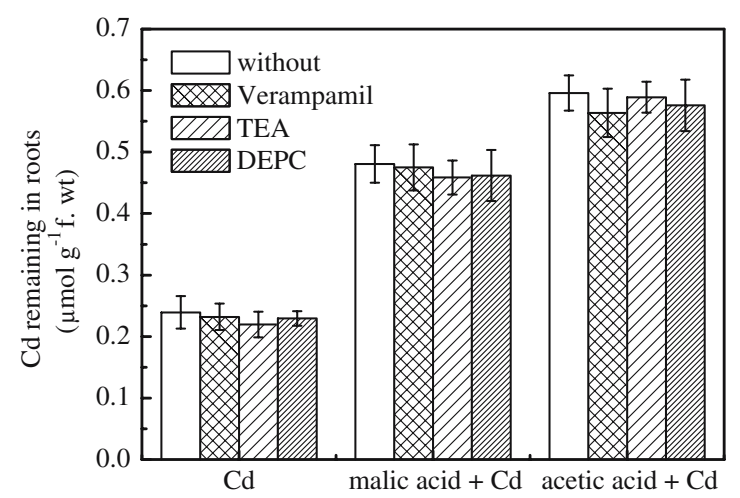

Fig. 5 Effects of $0.5 \mathrm{mM}$ verampamil, tetraethylammonium chloride (TEA-Cl), diethyl pyrocarbonate (DEPC) on the influx of $\mathrm{Cd}$ into maize (Zea mays L.) roots under the influence of organic acids. Values represent means $( \pm \mathrm{SE})$ of four replicates. Uniform maize roots were exposed for $4 \mathrm{~h}$. Cd concentration was maintained at $5.0 \mu \mathrm{M}$. The molar concentration ratio (organic acid:Cd) was 50:1. Desorption in $5 \mathrm{mM}$ ice-cold $\mathrm{CaCl}_{2}$ (5 mM Mes-Tris, $\mathrm{pH}$ 6.0) for $15 \mathrm{~min}$
Contribution of $\mathrm{Zn}^{2+}$ transporter to $\mathrm{Cd}$ influx

The influence of $\mathrm{Zn}$ or Fe deficiency on Cd uptake by maize roots was investigated to determine if $\mathrm{Zn}$ transporters potentially contributed to $\mathrm{Cd}$ influx. While Zn deficiency greatly enhanced Cd uptake, Fe deficiency had no statistically significant effect on Cd uptake relative to controls (Fig. 6). After inducing $\mathrm{Zn}$ deficiency, $\mathrm{Cd}$ accumulation in maize roots increased 3-fold when compared to maize roots incubated in full-nutrient solutions without the influence of organic acids $(P<0.01)$. With the application of acetic and malic acids $\mathrm{Cd}$ accumulation was also considerably enhanced by 4.0 and 3.6 times, respectively, in comparison with controls by inducing $\mathrm{Zn}$ deficiency $(P<0.01)$.

In addition, our results showed that without organic acids when $\mathrm{Zn}$ concentration in the incubation solution increased to $2.5 \mu \mathrm{M}, \mathrm{Cd}$ accumulation decreased to $87 \%$ of total $\mathrm{Cd}$ in maize roots incubated in full-nutrient solution $(P<0.01)$ (Fig. 7). As the $\mathrm{Zn}$ concentration was increased $\mathrm{Cd}$ uptake was inhibited, such that at $100 \mu \mathrm{M} \mathrm{Zn}, \mathrm{Cd}$ uptake was markedly inhibited to $38 \%(P<0.01)$. Further application of $\mathrm{Zn}$ to $250 \mu \mathrm{M}$ inhibited $\mathrm{Cd}$ content in roots to $30 \%$ $(P<0.01)$. The application of acetic and malic acids to a hydroponics solution containing

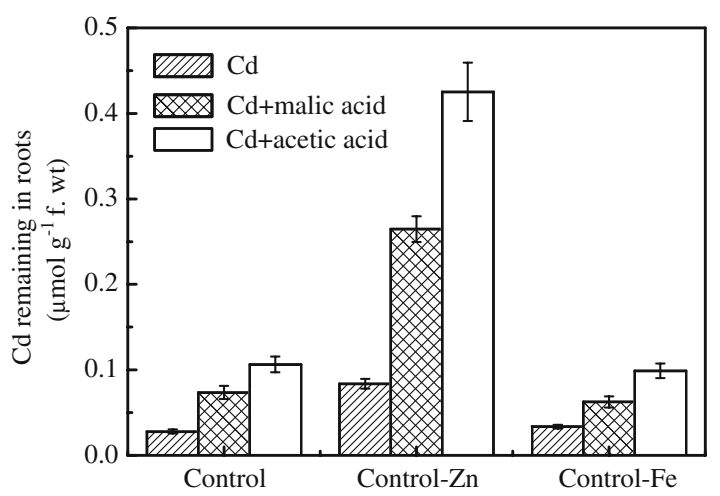

Fig. 6 Influence of $\mathrm{Zn}$ or Fe deficiency on $\mathrm{Cd}$ uptake by maize (Zea mays L.) roots in the presence of organic acids. Values are means $( \pm S E)$ of four replicates. $\mathrm{Zn}$ and $\mathrm{Fe}$ deficiency was induced for $6 \mathrm{~d}$, and thereafter the plants were transferred to uptake solutions containing $5.0 \mu \mathrm{M}$ $\mathrm{Cd}$. The molar concentration ratio (organic acids: $\mathrm{Cd}$ ) was 50:1. After 20 min uptake, uniform maize seedlings were harvested and roots desorbed in $5 \mathrm{mM}$ ice-cold $\mathrm{CaCl}_{2}$ (5 mM Mes-Tris, $\mathrm{pH} \mathrm{6.0)} \mathrm{for} 15 \mathrm{~min}$ 


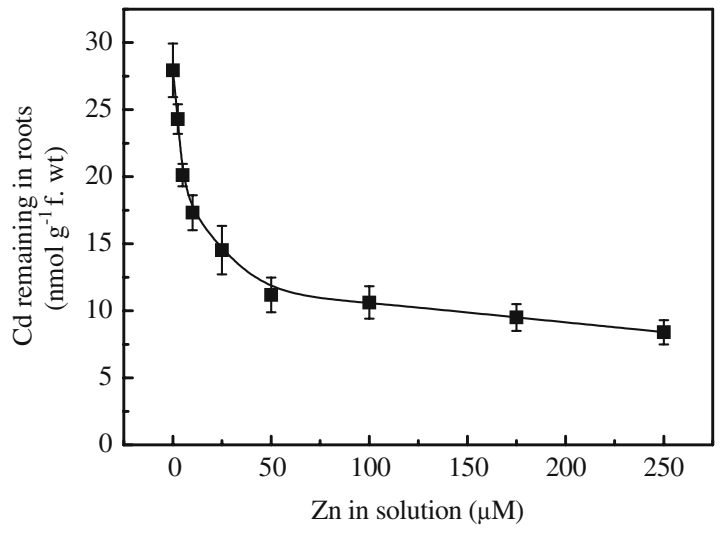

Fig. 7 Effect of different levels of $\mathrm{Zn}$ on $\mathrm{Cd}$ uptake by maize (Zea mays L.) roots without the application of organic acids. Values are means $( \pm S E)$ of four replicates. $\mathrm{Cd}$ concentration was maintained as $5.0 \mu \mathrm{M}$. Uniform maize seedlings were harvested after $20 \mathrm{~min}$ exposure and roots desorbed in $5 \mathrm{mM}$ ice-cold $\mathrm{CaCl}_{2}$ (5 mM Mes-Tris, $\mathrm{pH}$ 6.0) for $15 \mathrm{~min}$

$100 \mu \mathrm{M} \mathrm{Zn}$ also decreased $\mathrm{Cd}$ accumulation in maize roots to 26 and $30 \%$, respectively $(P<0.01)$ (Fig. 8).

Organic acids response to enhanced $\mathrm{Cd}$ accumulation in maize roots

The concentrations of various organic acids in undesorbed maize roots were determined by capillary electrophoresis, and the results are

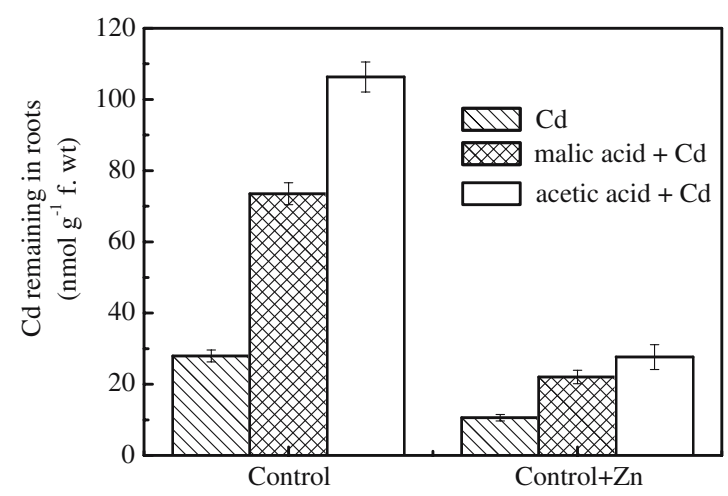

Fig. 8 Effect of Zn on Cd uptake by maize (Zea mays L.) roots under the influence of organic acids. Values are means $( \pm \mathrm{SE})$ of four replicates. Uniform maize seedlings were incubated in uptake solutions containing $5.0 \mu \mathrm{M} \mathrm{Cd}$ and $100 \mu \mathrm{M} \mathrm{Zn}$. The molar concentration ratio (organic acids:Cd) was 50:1. Seedlings were harvested after $20 \mathrm{~min}$ uptake and roots desorbed in $5 \mathrm{mM}$ ice-cold $\mathrm{CaCl}_{2}(5 \mathrm{mM}$ Mes-Tris, $\mathrm{pH}$ 6.0) for $15 \mathrm{~min}$ shown in Table 3. Enhanced Cd accumulation in maize roots due to the application of organic acids to the nutrient solution was accompanied by increased concentrations of acetic, formic, oxalate, malic, succinic, tartaric and citric acids in the maize roots. The enhanced organic acids were most probably produced in responses to excess $\mathrm{Cd}$ cation uptake, which could be a resistance strategy to Cd toxicity. Earlier studies have shown that, when plants are exposed to a heavy metal threat, organic acids may be produced in the plant cells as potential ligands for heavy metal complexation and therefore organic ligands play an important role in heavy metal tolerance and detoxification in plants (Rauser, 1999; Clemens, 2001).

\section{Discussion}

Enhanced Cd uptake by maize roots under the influence of organic acids

Our research showed that both acetic and malic acids could stimulate the uptake of $\mathrm{Cd}$ by maize roots. With a molar concentration ratio of 50:1 (organic acid:Cd), the $\mathrm{Cd}$ content of desorbed maize roots increased by 110 and $75 \%$ in the presence of acetic and malic acids respectively after $2 \mathrm{~d}$ of exposure compared with the control $(P<0.01)$ (Fig. 1).

The time dependent $\mathrm{Cd}$ uptake patterns were biphasic. For maize roots without $\mathrm{CaCl}_{2}$ desorption (Fig. 2a), the initial rapid phase (within the first $20 \mathrm{~min}$ ) was presumably due to diffusion of $\mathrm{Cd}$ into the free space and binding to the rootcell walls. The slower linear phase of Cd uptake over the subsequent 20-120 min may correspond to transport across the plasma membrane. For maize roots with $\mathrm{CaCl}_{2}$ desorption the dynamic uptake process resembled the report of Lasat et al. (1996) (Fig. 2b). The initial rapid component (within the first $10 \mathrm{~min}$ ) included cell-wall-associated $\mathrm{Cd}$ not removed by the desorption treatment. The slower linear phase of accumulation with exposure above $10 \mathrm{~min}$ was primarily due to $\mathrm{Cd}$ transport into the symplasm with a minor component due to undesorbed cell-wall-bound $\mathrm{Cd}$. 
The concentration-dependent uptake kinetics could be graphically resolved into saturable and linear components (modified Michaelis-Menten kinetics model: $\quad V=a C+V_{\max } C /\left(K_{m}+C\right)$, Fig. 4b). We suggest that the linear component represents cell-wall-bound $\mathrm{Cd}$ that remained after desorption. The saturable component of uptake indicates a transporter-limited process. Similar concentration-dependent kinetics has been reported for several other divalent cations, including Zn (Lasat et al., 1996), putrescine (DiTomaso et al., 1992), and paraquat (Hart et al., 1992). Acetic and malic acid increased $V_{\max }$ for $\mathrm{Cd}$ influx by 6.0 and 3.0 times, respectively, relative to the control $(P<0.001)$ (Table 1$)$. These results showed that in all treatments (with or without organic acid), Cd transported across the plasma membrane should be transporter-mediated, but the capacity of influx was much greater under the influence of organic acids.

How did Cd transport across the plasma membrane of maize roots under the influence of organic acids?

Till now the mechanisms of uptake, transport and accumulation of $\mathrm{Cd}$ in plants have not fully been understood. It is generally believed that $\mathrm{Cd}$ uptake by plants occurs mainly through cation channels or carriers. Lindberg et al. (2004) found that $\mathrm{Cd}$ uptake into the cytosol of wheat protoplasts takes place by channels permeable to $\mathrm{Ca}^{2+}$ and $\mathrm{K}^{+}$. Based mainly on uptake studies and growth effects, transporter proteins of the ZIP family were also proposed as possible transporters for Cd. Elevated IRTI transcription accompanied increased $\mathrm{Cd}$ accumulation in peas (Cohen et al., 1998). Higher accumulation of $\mathrm{Cd}$ was related to overexpressed AtIRT1 in Arabidopsis thaliana (Connolly et al., 2002). An increase in the abundance of TcIRT1-G mRNA in the Thlaspi caerulescens ectotype Ganges led to enhanced uptake of Cd (Lombi et al., 2002). Similar uptake and transport systems for $\mathrm{Cd}$ and $\mathrm{Zn}$ may exist in the $\mathrm{Cd}$ hyperaccumlator of Arabidopsis halleri (Küpper et al., 2000). The $\mathrm{Zn}$ transporter (ZNT1) has also been recently cloned from T. caerulescens and shown to mediate low-affinity uptake of Cd (Lasat et al., 2000; Pence et al., 2000).

Under the influence of organic acids, $\mathrm{Cd}$ transport across the root-cell plasma membrane of maize seedlings was also examined in this study. All of the blockers of $\mathrm{Ca}^{2+}, \mathrm{Na}^{+}$and $\mathrm{K}^{+}$ channels had no statistically significant inhibition effect on $\mathrm{Cd}$ influx into all treated maize roots (Fig. 5). Therefore, any Cd uptake through these cation channels was unfeasible. Iron deficiency had no statistically significant effect on $\mathrm{Cd}$ uptake, so $\mathrm{Cd}$ uptake via $\mathrm{Fe}$ transporters may not occur either. Only zinc deficiency exerted a stimulatory effect on Cd uptake in maize roots, which may be related to an up-regulation in the expression of genes encoding for $\mathrm{Zn}^{2+}$ uptake (Fig. 6). If similar uptake and transport systems for $\mathrm{Cd}$ and $\mathrm{Zn}$ exist in the roots of this maize cultivar, competitive transport interactions between these two ions may occur. Our experimental results demonstrated that the application of $\mathrm{Zn}$ could decrease $\mathrm{Cd}$ accumulation in maize roots in the absence (Fig. 7) or presence (Fig. 8) of acetic and malic acids. In addition, concentration-dependent net $\mathrm{Cd}$ influx in the presence and absence of organic acids could be resolved into linear and saturable components (Fig. 4b). The saturable component followed Michaelis-Menten kinetics, which indicated that $\mathrm{Cd}$ uptake across the plasma membrane should be transportermediated.

With the above results in mind, we conclude that $\mathrm{Cd}$ was most probably taken up into the maize roots by $\mathrm{Zn}$ transporter proteins. $\mathrm{Cd}$ and $\mathrm{Zn}$ are both metals from group IIb of the periodic table and exhibit numerous similar chemical properties and environmental behaviors. As $\mathrm{Cd}$ is not known to be an essential plant micronutrient, it is noteworthy that $\mathrm{Cd}$ uptake appears to occur via a carrier-mediated system. Previous studies reported the $K_{m}$ values for root $\mathrm{Zn}$ uptake ranged from $2 \mu \mathrm{M}$ to $8 \mu \mathrm{M}$ (Chaudhry and Loneragan, 1972; Lasat et al., 1996; Mullins and Sommers, 1986; Veltrup, 1978). The $K_{m}$ values from $0.16 \mu \mathrm{M}$ to $0.43 \mu \mathrm{M}$ for $\mathrm{Cd}$ uptake measured in this study are therefore comparatively lower (Table 1). Thus, if $\mathrm{Zn}$ and $\mathrm{Cd}$ shared a common influx pathway, the transporter appeared to have a greater affinity for $\mathrm{Cd}$. 
Table 2 Calculated $\mathrm{Cd}$ chemical species in the applied nutrient solutions at various organic acid:Cd molar concentration ratios $(50: 1,5: 1,2: 1)$

\begin{tabular}{|c|c|c|c|c|}
\hline \multirow[t]{2}{*}{ Treatment } & \multicolumn{4}{|l|}{ Cd speciation (\%) } \\
\hline & Complex constants & $50: 1$ & $5: 1$ & $2: 1$ \\
\hline \multirow{3}{*}{$\begin{array}{l}\text { Acetic acid } \\
\qquad(\mathrm{Ac})+\mathrm{Cd}\end{array}$} & {$\left[\mathrm{Cd}(\mathrm{Ac})_{2}\right]^{0}(3.15)$} & 82.7 & 61.4 & 38.5 \\
\hline & {$[\mathrm{Cd}(\mathrm{Ac})]^{+}(1.90)$} & 14.7 & 32.7 & 42.2 \\
\hline & {$[\mathrm{Cd}]^{2+}$} & 2.6 & 5.9 & 19.3 \\
\hline \multirow{3}{*}{$\begin{array}{l}\text { Malic acid } \\
\quad(\mathrm{Mal})+\mathrm{Cd}\end{array}$} & {$[\mathrm{Cd}(\mathrm{Mal})]^{0}(5.36)$} & 89.6 & 72.8 & 59.6 \\
\hline & {$[\mathrm{Cd}(\mathrm{HMal})]^{+}(2.34)$} & 8.2 & 23.4 & 28.7 \\
\hline & {$[\mathrm{Cd}]^{2}$} & 2.2 & 3.8 & 11.7 \\
\hline
\end{tabular}

Cd concentration was maintained at $5.0 \mu \mathrm{M}$

How did organic acids enhance Cd uptake by maize roots?

In this study, acetic and malic acids enhanced $\mathrm{Cd}$ uptake by maize roots in the order: acetic acid $>$ malic acid. The complex capacity of acetic acid with $\mathrm{Cd}^{2+}$ is lower than that of malic acid with $\mathrm{Cd}^{2+}$ (Table 2). This phenomenon is similar to our previous findings (Han et al., 2005), which showed that the lower the stability constants of organo-metallic complexes the greater the metal uptake. In addition, speciation calculations indicated that in the incubation solutions containing organic acid, Cd was mainly chelated with organic acid ( $>80 \%$, Table 2 ).

No nutrient carriers are thought to exist for organo-metallic complexes in the plasma membrane (Bell et al., 2003). Diffusion of charged or polar chelates across the plasma membrane at any significant rate is unlikely since synthetic chelates are too large and too polar to move through the plasmalemma lipid bilayer (Berne and Levy, 1998). On the basis of the size and polarity of the intact $\mathrm{Cd}(\mathrm{II})$-organic acid complexes, absorption of intact $\mathrm{Cd}(\mathrm{II})$-organic acid complexes was unlikely and free $\mathrm{Cd}$ ions were more easily available to maize roots than intact $\mathrm{Cd}(\mathrm{II})-$ organic acid complexes. Investigations on the influence of various molar concentration ratios of organic acids to $\mathrm{Cd}$ on $\mathrm{Cd}$ uptake by maize roots (Fig. 1) and relevant $\mathrm{Cd}$ chemical species calculations (Table 2) showed that the more $\mathrm{Cd}$ complexed with organic acids, the greater the enhanced Cd uptake. Nor and Cheng (1986) reported that plant roots were able to liberate trace metals from dissolved organo-metallic complexes once they were associated with the root zone.

Therefore, a possible mechanism to explain the observed effects of organic acids on Cd uptake was that, when $\mathrm{Cd}(\mathrm{II})$-organic acid complexes

Table 3 Contents ${ }^{\mathrm{a}}$ of organic acids in maize (Zea mays L.) roots

\begin{tabular}{|c|c|c|c|c|c|c|c|}
\hline $\begin{array}{l}\text { Organic } \\
\text { acid }\end{array}$ & $\mathrm{N}^{\mathrm{b}}$ & $\mathrm{N}+$ malic acid & $\begin{array}{l}\mathrm{N}+\text { acetic } \\
\text { acid }\end{array}$ & $\mathrm{N}+\mathrm{Cd}$ & $\begin{array}{l}\mathrm{N}+\mathrm{Cd}+\text { malic } \\
\text { acid }\end{array}$ & $\begin{array}{l}\mathrm{N}+\mathrm{Cd}+\text { acetic } \\
\text { acid }\end{array}$ & $\begin{array}{l}\text { Detection } \\
\text { limit }\end{array}$ \\
\hline $\begin{array}{r}\text { Acetic } \\
\text { acid }\end{array}$ & $0.56 \pm 0.04$ & $0.49 \pm 0.04$ & $0.56 \pm 0.04$ & $0.53 \pm 0.02$ & $1.30 \pm 0.08^{* *}$ & $1.32 \pm 0.09^{* *}$ & 0.04 \\
\hline $\begin{array}{l}\text { Formic } \\
\text { acid }\end{array}$ & $1.30 \pm 0.08$ & $1.28 \pm 0.08$ & $1.43 \pm 0.08$ & $1.25 \pm 0.06$ & $1.68 \pm 0.09^{*}$ & $2.9 \pm 0.1^{* *}$ & 0.08 \\
\hline $\begin{array}{r}\text { Lactic } \\
\text { acid }\end{array}$ & $0.171 \pm 0.009$ & $0.143 \pm 0.008$ & $0.155 \pm 0.009$ & $0.134 \pm 0.006$ & $0.18 \pm 0.02$ & $0.166 \pm 0.004$ & 0.05 \\
\hline $\begin{array}{r}\text { Oxalic } \\
\text { acid }\end{array}$ & nd & $0.020 \pm 0.002^{* *}$ & $0.041 \pm 0.004^{* *}$ & $0.049 \pm 0.005^{* *}$ & $0.058 \pm 0.005^{* *}$ & $0.078 \pm 0.005^{* *}$ & 0.05 \\
\hline $\begin{array}{l}\text { Malic } \\
\text { acid }\end{array}$ & $0.81 \pm 0.04$ & $1.10 \pm 0.06^{*}$ & $1.19 \pm 0.06^{*}$ & $1.07 \pm 0.06^{*}$ & $1.9 \pm 0.1^{* *}$ & $3.6 \pm 0.20^{* *}$ & 0.06 \\
\hline $\begin{array}{l}\text { Succinic } \\
\text { acid }\end{array}$ & $0.074 \pm 0.004$ & $0.089 \pm 0.006$ & $0.114 \pm 0.006^{*}$ & $0.094 \pm 0.006$ & $0.144 \pm 0.008^{* *}$ & $0.26 \pm 0.01^{* *}$ & 0.04 \\
\hline $\begin{array}{l}\text { Tartaric } \\
\text { acid }\end{array}$ & $0.173 \pm 0.012$ & $0.27 \pm 0.02^{*}$ & $0.26 \pm 0.02^{*}$ & $0.27 \pm 0.02^{*}$ & $0.45 \pm 0.02^{* *}$ & $0.63 \pm 0.04^{* *}$ & 0.06 \\
\hline $\begin{array}{l}\text { Citric } \\
\text { acid }\end{array}$ & $0.110 \pm 0.006$ & $0.14 \pm 0.01^{*}$ & $0.16 \pm 0.01^{*}$ & $0.143 \pm 0.008^{*}$ & $0.27 \pm 0.01^{* *}$ & $0.51 \pm 0.03^{* *}$ & 0.04 \\
\hline
\end{tabular}

Cd concentration was maintained as $5.0 \mu \mathrm{M}$. The molar concentration ratio (organic acid:Cd) was 50:1. Data are means $\pm \operatorname{SE}(n=4)$

${ }^{\text {a }}$ Units are $\mu \mathrm{mol} \mathrm{g}{ }^{-1}$ fresh root; nd, not detectable; ${ }^{\mathrm{b}} \mathrm{N}$ is nutrient solution; ${ }^{*} P<0.05 ;{ }^{* *} P<0.01$ 
became associated with the root zone, they could be decomposed and $\mathrm{Cd}^{2+}$ liberated. Subsequently free $\mathrm{Cd}\left(\mathrm{Cd}^{2+}\right)$ could be readily absorbed by maize roots in the layer of the roots or within the root free space. Depletion of $\mathrm{Cd}^{2+}$ would be buffered by the presence of $\mathrm{Cd}(\mathrm{II})$-organic acid complexes at higher solution organic acids concentrations. This mechanism also explained why acetic acid exerted greater effect than malic acid did, since acetic acid had a lower association constant for $\mathrm{Cd}$ and would form more labile complexes. Senden et al. (1995) reported a similar effect on the $\mathrm{Cd}$ uptake and distribution among tomato plant roots in the presence of citric acid.

In addition, $\mathrm{K}^{+}$efflux to the external solution and $\mathrm{K}^{+}$contents in the roots were similar regardless of treatment (Fig. 9). This demonstrated that membrane integrity was not adversely affected by the application of $250 \mu \mathrm{M}$ organic acid and $5.0 \mu \mathrm{M} \mathrm{Cd}$. Consequently, the enhancement of $\mathrm{Cd}$ uptake under the influence of organic acids was not due to toxicological action.

The major conclusions from this study, resulting from the influence of organic acids, were: (1) the maximum influx rate $\left(V_{\max }\right)$ for $\mathrm{Cd}$ uptake into maize root cells was enhanced; (2) dissolved Cd(II)-organic acid complexes could be decom-

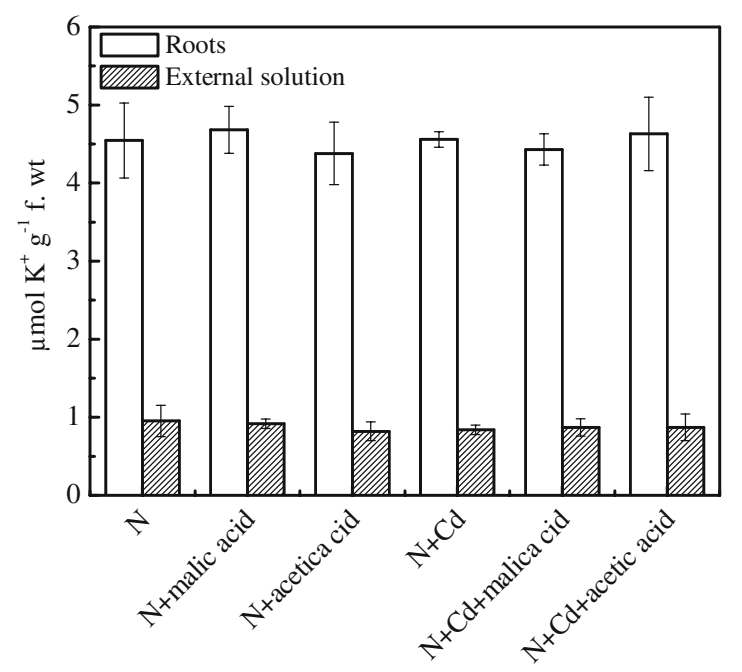

Fig. 9 Potassium efflux to the external solution and $\mathrm{K}^{+}$ contents in maize (Zea mays L.) roots after treatment for $2 \mathrm{~d}$ with and without the presence of $250 \mu \mathrm{M}$ organic acid and $5.0 \mu \mathrm{M} \mathrm{Cd}$. Values are means $( \pm \mathrm{SE})$ of four replicates. $\mathrm{N}$ : nutrient solution posed and liberate $\mathrm{Cd}^{2+}$ when they were associated with the maize root surface. However, direct compelling evidence for this speculation needs further detailed study; (3) the enhanced influx of $\mathrm{Cd}$ into maize roots was most probably mediated by $\mathrm{Zn}$ transporters; (4) concentrations of natural organic acids in maize roots were greatly increased when Cd uptake was enhanced, and their complexation with $\mathrm{Cd}$ supposedly contributed to $\mathrm{Cd}$ detoxification in maize roots.

Acknowledgements This study was supported by the National Natural Science Foundation of China (Grant 20237010 and 20177030). We thank Prof. Naibing Bai (Institute of Software, Chinese Academy of Sciences) for generous help in $\mathrm{Cd}$ speciation calculations.

\section{References}

Bell PF, McLaughlin MJ, Cozens G, Stevens DP, Owens $\mathrm{G}$, South H (2003) Plant uptake of ${ }^{14} \mathrm{C}$-EDTA, ${ }^{14} \mathrm{C}$ Citrate, and ${ }^{14} \mathrm{C}$-Histidine from chelator-buffered and conventional hydroponic solutions. Plant Soil 253:311-319

Berne RM, Levy MN (1998) Physiology. Mosby, Inc., St. Louis, MO USA, $1131 \mathrm{pp}$

Chaudhry FM, Loneragan JF (1972) Zinc absorption by wheat seedlings and the nature of its inhibition by alkaline earth cations. J Exp Bot 23:552-560

Cieśliński G, Van Rees KCJ, Szmigielska AM, Krishnamurti GSR, Huang PM (1998) Low-molecular-weightorganic acids in rhizosphere soils of durum wheat and their effect on cadmium bioaccumulation. Plant Soil 203:109-117

Clemens S (2001) Molecular mechanisms of plant metal tolerance and homeostasis. Planta 212:475-486

Cohen CK, Fox TC, Garvin DF, Kochian LV (1998) The role of iron-deficiency stress responses in stimulating heavy-metal transport in plants. Plant Physiol 116:1063-1072

Connolly EL, Fett JP, Guerinot ML (2002) Expression of the IRT1 metal transporter is controlled by metals at the levels of transcript and protein accumulation. Plant Cell 14:1347-1357

DiTomaso JM, Hart JJ, Kochian LV (1992) Transport kinetics and metabolism of exogenously applied putrescine in roots of intact maize seedlings. Plant Physiol 98:611-620

Dudka S, Miller WP (1999) Accumulation of potentially toxic elements in plants and their transfer to human food chain. J Environ Sci Health, Part B 34:681-708

Essah PA, Davenport R, Tester M (2003) Sodium influx and accumulation in arabidopsis. Plant Physiol 133:307-318

Han F, Shan XQ, Zhang J, Xie YN, Pei ZG, Zhang SZ, Zhu YG, Wen B (2005) Organic acids promote the 
uptake of lanthanum by barley roots. New Phytol 165:481-492

Hart JJ, Di Tomaso JM, Linscott DL, Kochian LV (1992) Characterization of the transport and cellular compartmentation of paraquat in roots of intact maize seedlings. Pestic Biochem Physiol 43:212-222

Hart JJ, Welch RM, Norvell WA, Sullivan LA, Kochian LV (1998) Characterization of cadmium binding, uptake, and translocation in intact seedlings of bread and durum wheat cultivars. Plant Physiol 116:14131420

Hill KA, Lion LW, Ahner BA (2002) Reduced Cd accumulation in Zea mays: a protective role for phytosiderophores. Environ Sci Technol 36:5363-5368

Huang JW, Blaylock MJ, Kapulnik Y, Ensley BD (1998) Phytoremediation of uranium-contaminated soils: role of organic acids in triggering uranium hyperaccumulation in plants. Environ Sci Technol 32:2004-2008

Jones DL (1998) Organic acids in the rhizosphere-a critical review. Plant Soil 205:25-44

Jones DL, Darrah PR (1994) Role of root derived organic acids in the mobilization of nutrients from the rhizosphere. Plant Soil 166:247-257

Keller C, Hammer D, Kayser A, Richner W, Brodbeck M, Sennhauser M (2003) Root development and heavy metal phytoextraction efficiency: comparison of different plant species in the field. Plant Soil 249:67-81

Krishnamurti GSR, Cieśliński G, Huang PM, Van Rees KCJ (1997) Kinetics of cadmium release from soils as influenced by organic acids: implication in cadmium availability. J Environ Qual 26:271-277

Küpper H, Lombi E, Zhao FJ, McGrath SP (2000) Cellular compartmentation of cadmium and zinc in relation to other elements in the hyperaccumulator Arabidopsis halleri. Planta 212:75-84

Lasat MM, Baker AJM, Kochian LV (1996) Physiological characterization of root $\mathrm{Zn}^{2+}$ absorption and translocation to shoots in $\mathrm{Zn}$ hyperaccumulator and nonaccumulator species of Thlaspi. Plant Physiol 112:1715-1722

Lasat MM, Pence NS, Garvin DF, Ebbs SD, Kochian LV (2000) Molecular physiology of zinc transport in the Zn hyperaccumulator Thlaspi caerulescens. J Exp Bot 51:71-79

LIamas A, Ullrich CI, Sanz A (2000) $\mathrm{Cd}^{2+}$ effects on transmembrane electrical potential difference, respiration and membrane permeability of rice (Oryza sativa $\mathrm{L}$.) roots. Plant Soil 219:21-28

Lindberg S, Landberg T, Greger M (2004) A new method to detect cadmium uptake in protoplasts. Planta 219:526-532

Lombi E, Tearall KL, Howarth JR, Zhao FJ, Hawkesford MJ, McGrath SP (2002) Influence of iron status on cadmium and zinc uptake by different ecotypes of the hyperaccumulator Thlaspi caerulescens. Plant Physiol 128:1359-1367

López-Bucio J, Nieto-Jacobo MF, Ramírez-Rodríguez V, Herrera-Estrella L (2000) Organic acid metabolism in plants: from adaptive physiology to transgenic varieties for cultivation in extreme soils. Plant Sci 160:1-13
Montague MJ (1993) Calcium antagonists inhibit sustained gibberellic acid-induced growth of Avena (oat) stem segments. Plant Physiol 101:399-405

Mullins GL, Sommers LE (1986) Cadmium and zinc influx characteristics by intact corn (Zea mays L.) seedlings. Plant Soil 96:153-164

Nigam R, Srivastava S, Prakash S, Srivastava MM (2000) Effect of organic acids on the availability of cadmium in wheat. Chem Spec Bioavailab 12:125-132

Nor YM, Cheng HH (1986) Chemical speciation and bioavailability of copper: uptake and accumulation by Eichornia. Environ Toxicol Chem 5:941-947

Norvell WA, Welch RM (1993) Growth and nutrient uptake by barley (Hordeum vulgare L. cv Herta). Studies using an $\mathrm{N}$-(2-hydroxyethyl)ethylenedinitrilotriacetic acid-buffered nutrient solution technique. Plant Physiol 101:619-625

Pellet DM, Grunes DL, Kochian LV (1995) Organic acid exudation as an aluminum-tolerance mechanism in maize (Zea mays L.). Planta 196:788-795

Pence NS, Larsen PB, Ebbs SD, Letham DLD, Lasat MM, Garvin DF, Eide D, Kochian LV (2000) The molecular physiology of heavy metal transporter in the $\mathrm{Zn} /$ Cd hyperaccumulator Thlaspi caerulescens. Proc Natl Acad Sci USA 97:4956-4960

Piñeros MA, Magalhaes JV, Carvalho Alves VM, Kochian LV (2002) The physiology and biophysics of an aluminum tolerance mechanism based on root citrate exudation in Maize. Plant Physiol 129:1194-1206

Qin F, Shan XQ, Wen B (2004) Effects of low-molecularweight organic acids and residence time on desorption of $\mathrm{Cu}, \mathrm{Cd}$, and $\mathrm{Pb}$ from soils. Chemosphere 57:253263

Rauser WE (1987) Compartmental efflux analysis and removal of extracellular cadmium from roots. Plant Physiol 85:62-65

Rauser WE (1999) Structure and function of metal chelators produced by plants-the case for organic acids, amino acids, phytin and metallothioneins. Cell Biochem Biophys 31:19-48

Robinson BH, Leblanc M, Petit D, Brooks RR, Kirkman JH, Gregg PEH (1998) The potential of Thlaspi caerulescens for phytoremediation of contaminated soils. Plant Soil 203:47-56

Schwartz C, Echevarria G, Morel JL (2003) Phytoextraction of cadmium with Thlaspi caerulescens. Plant Soil 249:27-35

Senden MHMN, van der Meer AJGM, Verburg TG, Wolterbeek HTH (1995) Citric acid in tomato plant roots and its effect on cadmium uptake and distribution. Plant Soil 171:333-339

Shan XQ, Lian J, Wen B (2002) Effect of organic acids on adsorption and desorption of rare earth elements. Chemosphere 47:701-710

Shan XQ, Wang HO, Zhang SZ, Zhou HF, Zheng Y, Yu H, Wen B (2003) Accumulation and uptake of light rare earth elements in a hyperaccumulator Dicropteris dichotoma. Plant Sci 165:1343-1353

Smith RM, Martell AE, Motekaitis RJ (1997) NIST critically selected stability constants of metals complexes database. Version 4.0. US Department of 
Commerce, National Institute of Standards and Technology, Gaithersburg, MD

Srivastava S, Prakash S, Srivastava MM (1999) Chromium mobilization and plant availability-the impact of organic complexing ligands. Plant Soil 212:203-208

Veltrup W (1978) Characteristics of zinc uptake by barley roots. Physiol Plant 42:190-194

Wang WS, Shan XQ, Wen B, Zhang SZ (2004a) A method for predicting bioavailability of rare earth elements in soils to maize. Environ Toxicol Chem 23:767-773

Wang ZW, Zhang SZ, Shan XQ (2004b) Effects of lowmolecular-weight-organic-acids on uptake of lanthanum by wheat roots. Plant Soil 261:163-170
Westall JC, Zachary JL, Morel FMM (1976) MINEQL: a computer program for the calculation of chemical equilibrium composition of aqueous systems. Parsons RM Laboratory, Massachusettes Institute of Technology

Zhao FJ, Lombi E, McGrath SP (2003) Assessing the potential for zinc and cadmium phytoextraction with the hyperaccumulator Thlaspi caerulescens. Plant Soil 249:37-43 